\title{
Control of Capital Against the Middle Income Trap
}

\begin{abstract}
Developing countries now significantly advanced in development, which include Poland, have much lower productivity of production factors, including workforce productivity. Among the reasons for that, essential is the unfavorable division of labor in the global value creation chain. Such a condition in the post-socialist countries results from several important factors, among them accelerated privatization, mainly with the participation of foreign capital, as well as the structure of foreign direct investments. The national economy is dominated by foreign corporations that invested labor-intensive production processes in these countries, using cheap labor. The subordinate role of local production has been strengthened by the globalization process. These countries may be caught in the trap of medium development, and currently operate in a peculiar lower league of the world economy. The inferior role of local subcontractors is due to the fact that they do not participate in the capital ownership of companies and thus have little influence on the power of international corporations. Improving their position requires an active policy of states, including the control of gross capital flow structure.
\end{abstract}

Keywords: Capital Management; Capital Flow; Smile Curve; Subcontractor Role; Second League Economy; Threats of Reshoring; International Value Creation Chain.

\section{Introduction}

Polish economy is threatened with decelerated pace of growth due to depletion of factors that give it a comparative advantage in relation to highly developed economic and trade partners. This may happen because effects of an unfavorable division of labor, which Poland was given in the international value creation chain of goods and services, will emerge. Favorable position occupied in this chain is determined by capital, which gives power to dominant international corporations. Improving this position requires more effective capital management.

Poland, being a small open economy, has achieved significant economic progress in the last quarter of a century, after major systemic transformation. 
High growth rates were facilitated by significant resources of well-educated and cheap workforce, trained for production in the conditions of industrialization, in the process of an ineffective so-called socialist industrialization. Human resources remained available to investors, local and foreign, in a largely urbanized country. It can be added that advantageous geographical location of Poland, in the close vicinity of the core of the European Union, also played a role.

The political transformation at the beginning of the 1990s brought about a radical change in the Polish economy called a "shock therapy”. In effect of accelerated privatization, part of the „shock therapy”, the basic production plants were taken over by foreign capital due to the lack of domestic capital. Attractive conditions have been created to encourage foreign direct investment (FDI). Foreign investors used this incentive, i.e., above all, cheap labor, transferring labor-intensive production processes to Poland. At times, privatization consisted in the sale of the market segment, where the privatized company concerned was soon closed and the gap in the domestic market was filled by a foreign producer. However, in most cases industrial plants underwent restructuring - they were modernized and became contractor for production commissioned by the new owner. At that stage of development of the Polish economy, however, this brought improved productivity, workforce efficacy and, as a result, benefits to both parties, foreign owners - managers as well as domestic contractors. Therefore, it was offshoring beneficial to both sides.

In the value-creation chain, the company was at the bottom of the value creation chain described as the "smile curve" in which the highest added value margin is obtained by companies located at the beginning and end of the chain.

It works this way because, on both raised edges, the price of the product and the added value is created by the owners of capital, creators of the producer's brand, designers, organizers of the production cooperation chain, those managing this chain, and marketing specialists. Business services are situated be below, including: accounting, financial, legal, logistic, others, and in the middle of the curve i.e. its lowest segment - factory activity rests. Thus the most profitable activity are located at far ends of the curve. I will modestly call them management.

Unfortunately, this management is not a Polish specialty in the international division of labor. This privileged deposit is determined by the ownership of capital and thus the power, and it belongs to the shareholders and subordinate managers managing the corporation, even if the latter are recruited from among domestic residents. As everyone knows, the capital does not have a homeland, while its shareholders have or even more often chose it in tax havens. 
The awakened entrepreneurial activity of the society under the new political conditions, and at the same time a significant inflow of capital, privatization through the purchase of state enterprises by foreign investors and new direct investments from abroad, have resulted in Poland becoming rapidly involved in the process of globalization of the world economy, and achieving clear benefits. However, unfortunately, this also meant becoming exposed to certain restrictions, or even threats that only have become apparent over time.

Globalization and global markets have therefore consolidated both the domestic producers and foreign investors investing in Poland in the same position - a subordinate place in the value creation chain of products and services. These were the roles of a cooperator, subcontractors or contractors of final products commissioned by international corporations. However, this was not at all unfavorable under condition of the Polish economy at the time.

Foreign direct investment contributed significantly to employment growth and labor productivity but they hardly brought any breakthrough in dissemination of new technologies because they were transferring only parts of the production processes. This character of investments is well illustrated by their performance measured by value added by individual industries, in which these investments were located. The effects of foreign direct investment (FDI) measured by the share in the creation of the Gross Domestic Product in Poland were studied by the "Polityka Insight" knowledge platform. Some of these results are presented in Table 1.

Table 1. Share of FDI in selected industries in expenditures and results

\begin{tabular}{|l|c|c|}
\hline & $\begin{array}{c}\text { Industry structure of inflow } \\
\text { of foreign investments (FDI) }\end{array}$ & $\begin{array}{c}\text { Share of industries in GDP } \\
\text { growth thanks to these } \\
\text { investments (FDI) }\end{array}$ \\
\hline Industrial processing & $32 \%$ & $17 \%$ \\
\hline Construction & $4 \%$ & $6 \%$ \\
\hline Trade & $16 \%$ & $19 \%$ \\
\hline Other services & $52 \%$ & $68 \%$ \\
\hline
\end{tabular}

Source: Czerniak and Blauth, 2017.

Although foreign investments brought new technologies to Poland, these were from the area of processing production, bringing relatively small increase in value added in industrial and construction activities, while it was higher in trade and especially in other services. However, a much more important result was their impact on extending export opportunities, which was important for improving the country's balance of payments. 
The opening of the economy to globalization processes also brought new organizational experience in the field of international economic and trade relations ${ }^{1}$ as well as wide access to capital, access to foreign markets and increased exports. The productivity of labor and wages also increased, so the Polish economy shortened the development gap toward more developed countries. In these circumstances the legitimacy of adopting, by Poland, of institutions shaped in Europe is a fact Dani Rodrik finds remarkable (Rodrik, 2011). Reforms carried out and good state finances also enable Poland to meet the criteria for the country's accession to the European Union in 2004. The common EU market has become another major impulse for development. The real convergence process was progressing, additionally strengthened by EU solidarity funds. The global economic crisis of 2008-2009 only slowed down the growth rate, but without stopping the convergence process altogether. Also, the current recovery, or indeed the good economic situation in the world economy, allows to continue this process, although, as it seems, not for long. The role of the subcontractor will inevitably make itself known. The real convergence process will cease. The country may fall into the middle income trap. This term, although widely used to define the situation of a given country, in my opinion is not really appropriate in the case of the Polish economy. It is better to use the terminology of sports: the country remains a permanent player in the lower league of the world economy, with a small chance of promotion to the premier league. Sure it may develop, but it will not reach the level of GDP per capita, and thus also the well-being, of citizens of highly developed countries. The main reason is the lower productivity of work, resulting from less favorable place in the value creation chain (Global Wealth Chain). What we are witnessing is not a good division of labor between equal partners, because the partners involved are not equal. The principle of comparative advantages of David Ricardo cannot be applied here, because the world economy is different than it used to be two centuries ago. This theory postulates that everyone should do what they can do best and the cheapest, whereas in the conditions created by globalization everyone can do the same final product, only different activities are performed in different countries. ${ }^{2}$

1 Rodrik points out that Poland has undergone a similar historical path as other European countries. Imitating institutions that were created in Europe could have been useful in Polish conditions (Rodrik, 2011).

2 For example, the French are promoting fashion of cloths and organize the production, peoples in East Asia weave and sew, and Poles keep the accounts and transport the products. All of them work in this by no means the most modern sector of the economy, but they bring different added value, which results in different remuneration and different levels of participation in generating GDP. 


\section{The Trap or the Second League}

The rate of economic growth in Poland is still higher than in neighboring highly developed countries, and recently it even reaches $4-5 \%$ per year when neighbors record the growth rate only half as high. Facing this, one could ask a question where this fear comes from about the future of the Polish economy to stop the real convergence process. The answer is the fear results from several reasons.

Poland's advance in the economic development means that the risk of the middle income trap is, for the time being, rather unlikely. The level of GDP per capita according to purchasing power parity is slightly more than $50 \%$ of the GDP of the richest neighbor - Germany, and about $70 \%$ of respective level of 19 countries of the "old" European Union. Poland is closer to developed countries than most emerging markets. In the review of world literature on the trap of the medium level of development, Andrzej Wojtyna (2016, p. 8) states that the "definitions of the "trap" can be divided into a qualitative (descriptive) and quantitative nature. In the case of the former, attention is often drawn to the difficulties in shifting countries on the medium level of development up the international value chain. In this approach, the barriers to growth are primarily of a microeconomic nature, and therefore their overcoming requires the use of specific industrial policy tools." Poland may fall in this type of trap, also playing in the lower league of the world economy. In this case, traditional industrial policy, or more broadly - sectoral policy, will no longer suffice. The question then arises whether in the search for a way to counteract such a form of the medium level development trap, one can use the New Structural Economics (NSE) method formulated by J.Y. Lin (Lin and Nowak, 2018). The promotion of sectors with higher added value, in this case, will not bring the desired results, because individual sectors, including those of this type, already exist in the country, but the place of domestic producers in these sectors is unfavorable, subordinate. This is due to the ownership structure and functions of value chain management in individual corporations. It is therefore about using capital management instruments to avoid the dangers of staying permanently in the "second league" of countries advanced in development, condemned to lower labor productivity and thus to a lower margin of value added per employee. This condition is an unfavorable result of much desirable but hasty privatization and of the inflow of FDI, also desired but not always meeting the expectations.

The successful economic development of Poland's trade partners, especially European Union countries, favors the economic growth of countries remaining in the lower league of the European economy. The "smile curve" productivity 
curve can even smoothen towards the straight line, first of all because the share increases in generating GDP of higher-priced services compared to factory operations, in particular business services. They can also grow and indeed increase wages in production and services, both as a result of an increase in the level of qualifications of employees, better technical equipment of jobs, and as a result of the situation on the labor market. The resources of cheap labor are becoming exhausted and here some new threats also arise, as considered further on.

Secondly, small and medium-sized enterprises play major role in the Polish economy, including family businesses. Of course, these enterprises are managed by local entrepreneurs, which should favor higher productivity resulting from the position of property and power. However, the scale of business operations within these enterprises is small, so their productivity is also lower than in the case of companies forming a part of large corporations. The development of such enterprises must, however, face competition in a market dominated by large corporations. If these types of enterprises are not dominated by or bought by the competition, then as a result of their operations the smoothing of the productivity curve will also occur. In turn, all other small and medium-sized enterprises along with the depletion of labor resources will compete with each other for employees, which will also increase labor costs by forcing changes in work organization and investments to increase labor productivity in this sector as well. Such actions will, in the total effect, also contribute to the increase of added value. Unfortunately, such a course of events may turn out to be overly optimistic.

An increase in remuneration is the loss of an important element of competitive advantage. After all, lower labor costs were conducive to transferring laborintensive production processes to Poland and a range of services, including business ones. International corporations can transfer this type of activity further on, to cheaper labor countries. Thus, outsourcing, which served the Polish economy in the previous state of low wages and unemployment, at the beginning of building a market economy, can now become a threat if it leads to deterioration in the bargaining position of employees, or even to unemployment.

Thirdly - for developing countries and for countries much advanced but still playing in the lower league of the world economy, there is unfortunately a new threat resulting from the new industrial revolution called the "Generation Industry 4.0". Although the technological progress associated with this generation is enthusiastically hailed, countries that cannot keep up with the fast pace of high technology can lose a lot. This results not only from the consequences of disappearance of real convergence but may even cause divergence, deepening 
differences in the level of development (Ryć, 2017). Offshoring production processes from countries with high labor costs can turn into reshoring because of the digitization of production, intelligent factories that save human labor and thus its costs. The return of industrial processing to the parent countries of international corporations will cause serious problems for less developed countries. (Götz, 2018)

Therefore, there are enough reasons for countries less advanced in development to make efforts to advance from the second league up to the first.

\section{Managing the Structure of Capital Flow for the Desired Effects on the Microeconomic Scale}

There is a widespread opinion that innovation and entrepreneurship are the way to achieve high productivity. Innovation creates human and social capital, which consists of institutions conducive to innovation. Creating human capital requires financial outlays for scientific research and personnel training. It is also necessary to publicly support the incubation of entrepreneurship and the active role of the state in this field.

The protection of economic development by the state has worked well in history in the case of countries highly developed today. It also passed the exam in many formerly poor economies, especially in East and Southeastern Asia, currently highly developed or significantly advanced in development. This type of protectionism is excluded in the case of Poland - the European Union member state which after the systemic transformation has successfully entered the path of the liberal market economy, although it is exposed to the threat of staying in the status of a subcontractor's country.

The postulate of betting on innovations, their creation, formation of human and social capital is obvious. Capital expenditures for this purpose are justified. However, there is no guarantee that thanks to them, technological capacities that generate high added value will grow in the country. The reason for this are the unfavorable conditions for the "breeding" of champions comparable to those that the free market creates, let alone the common European market. You can only count on isolated cases, because the free flow of capital and the free market are not favorable. This is what J.S. Stiglitz expressed very firmly in his opinion which relates to the emerging market type, but also to Poland (Stiglitz, 2010, p. 258): "Liberalization of trade meant that foreign companies could "slaughter" the local populations in the industry, suppressing the development 
of entrepreneurial talents. When capital flowed freely, the flow of labor was limited - with the exception of the most talented individuals, many of whom found good employment in the global labor market." These sharp words of the Nobel Prize winner also refer to many initiatives and careers of outstanding individuals in Poland. However, they are not an excuse for Polish laments over the outflow of profits abroad from international corporations that have invested in Poland. They have the right to do so and we should remain kind to them for what they have done by creating jobs and for what they leave in Poland in the form of employee wages, usually higher than those in small and mediumsized enterprises, and taxes paid here. This does not mean, however, we should give up protection and not support domestic competitors also using capital resources, including through more effective management of the capital flow structure. Therefore, it is not about changing the rules of the game, but instead about more effective game for the entry of domestic capital into the position of management in an increasing part of important producers and service providers. Developing methods and tools for capital management, including shaping the capital structure at the microeconomic scale supporting industrial policy, seems to be a task that is viable according to the assumptions of the New Structural Economics.

At this point, you can indicate several directions of impact by means of capital.

1. In the first place we should place what almost all researchers consider important, namely the financial outlays for the growth of social and human capital. The point is to educate talented people and to retain the educated ones. To finance research but not to export its results in the raw form, which can be a source of innovation. Therefore, it is not the task of simply increasing the funds for this purpose, but for their well-thought-out structure securing the use of the invested capital. The structure of the funds involved should not only maximize growth, but also minimize the shortage and losses of this capital.

2. The state „breeding” of champions should be approached carefully. What was possible in East Asia cannot be repeated in Central Europe or in the common market. For example, in Poland, focus on electromobility in the passenger car industry without native innovations, has virtually no chance of going beyond the execution and assembly. Technologically advanced components will be purchased abroad even when foreign manufacturers want to manufacture them in Poland. The latter ones are in a favorable position that stems from their property, know-how and power. On the other hand, this does not mean that similar attempts should be abandoned altogether, 
but you also cannot - by the rules of the "old" Structural Economics, which, among others, allowed anti-import production - build on them a favorable position in the value creation chain ${ }^{3}$ (Lin and Nowak, 2018).

3. Control of the capital inflow and outflow structure: support of outsourcing to Poland of innovative projects reporting the demand for qualified, well-paid jobs and business services. However, one should also retain much reserve toward the transfer of simple production if it hardly makes it easier to solve, for example, local problems of the labor market.

4. Domestication of foreign capital by creating favorable conditions for introducing new technologies and reinvesting profits. In truth, today you cannot count on contemporary Wedel, Motels, or Blikle, foreign entrepreneurs and investors who had settled in Poland long ago and have been running their business for generations. Probably due to even greater social mobility, the permanent residence of foreign co-owners or owners is less likely.

5. It is possible to buy out, in whole or by shares in, foreign enterprises operating in the country by private non-public capital. This is not about repolonization, i.e. buy-out by state-owned companies, but first of all about the private sector, along with its strengthening on the capital market.

6. Deepening financial services not only for small and medium enterprises and beginning producers, but also for ambitious capital ventures of Polish producers, both in the country and abroad.

7. Intentional offshoring - Poland was and still is benefiting from the transfer of production of foreign companies to us. Today, we are afraid of their escaping to places with cheaper workforce. However, the offshoring of Polish companies to countries with lower production costs is relatively small. Now and in the future it is necessary to use the offshoring method on a larger scale and to transfer less efficient production beyond the borders of our country. Of course, on condition that this does not cause an increase in unemployment. Such activities of Polish entrepreneurs should gain stronger support.

\section{Conclusion}

The process of reaching a favorable position in the international value creation chain, with the help of an active policy of controlling the flow of capital,

3 The Polish company, which successfully produced buses with electric drive, also successfully exported them, was put up for sale and will probably end up in the hands of foreign investors. 
is by no means certain or even fast. Nonetheless, efforts in this field should be made because the country's staying in this lower league of the world economy is not only unsatisfying to the society but also dangerous. The threat is that of falling into an authentic trap of the medium level of development.

\section{References}

Czerniak, A. and Blauth, K. (2017). Co przyniosty inwestycje zagraniczne. Warsaw: Polityka Insight.

Götz, M. (2018). Przemysł czwartej generacji (przemysł 4.0) a międzynarodowa współpraca gospodarcza. Ekonomista, (4), 385-403.

Lin, J.Y. and Nowak, A.Z. (eds.). (2017). New structural economics for less advanced countries. Warsaw: Wydawnictwo Naukowe Wydziału Zarządzania Uniwersytetu Warszawskiego.

Rodrik, D. (2011). Jedna ekonomia wiele recept. Warsaw: Krytyka Polityczna.

Ryć, K. (2017). The expiring real convergence process under conditions of the common market - how to counteract. In: J.Y. Lin, A.Z. Nowak (eds.), New structural economics for less advanced countries (p. 69-79). Warsaw: Wydawnictwo Naukowe Wydziału Zarządzania Uniwersytetu Warszawskiego.

Stiglitz, J.E. (2010). Freefall. Warsaw: Polskie Towarzystwo Ekonomiczne.

Wojtyna, A. (2016). Standardowe i niestandardowe działania antykryzysowe. Gospodarka Narodowa, (6), 5-22. 